\title{
REDISCOVERING PAST NARRATIONS: THE ORAL HISTORY OF THE ROMANIAN LANGUAGE PRESERVED IN THE NATIONAL PHONOGRAM ARCHIVE
}

\author{
Oana Niculescu*, Maria Marin** \& Daniela Răuţu***
}

\begin{abstract}
In this paper we aim to deliver a key message related to the safeguarding of the Romanian National Phonogram Archive (AFLR). The data gathered within the Archive (the richest, most inclusive and diversified collection of dialectal texts and ethno-linguistic recordings in Romania) are of immeasurable documentary value. Through the digitization and preservation of AFLR we can gain access to both individual and collective memories, aiding to a better understanding of our cultural heritage on the one hand, and, on the other hand, restoring missing or forgotten pieces of Europe's oral history.
\end{abstract}

Keywords: AFLR, dialect texts, cultural heritage, digitization, MIDVAL

\section{Introduction}

The aim of this paper ${ }^{1}$ is to raise awareness concerning the protection and preservation of the Romanian Phonogram Archive (AFLR), a repository of the oral history of the country. The collection shelters numerous past narrations recorded on reelto-reel tapes accompanied by hand written "village notebooks" compiled during field work. These narrations showcase significant events surrounding birth, marriage or death and the corresponding customs, everyday activities, memories and anecdotes, brief biographies, recipes, songs and carols, stories and fables told by children. Alongside these lively renditions of village life, we can also find unique accounts regarding the name and origin of various settlements, rivers and landmarks.

The dialectal texts collected in the Archive, the stories and folkloric productions pertain to a certain mentality and belief system, one which has endured multiple challenges, both historical and political. Designed to be representative of all DacoRomanian subdialects, both in the country and across the borders, AFLR is an authentic collection of dialectal texts (Marin 1996, 2003, 2012). The purpose of such collections is to preserve the oral history, traditions, customs and folklore of the population.

At present, there is an urgent need to digitize the Archive in order to prevent further degradation or even possible loss of the entire collection. Either stored on tapes (audio files) or registered on notebooks (text files), all these documents need to undergo an efficient and coherent digitization process. This process will ensure a long-term digital engagement orientated towards the entire retrieval of the Archive.

The article is organized in four sections. Introductory remarks are presented in the first part, followed by a theoretical and methodological presentation of the Archive. In the

\footnotetext{
* “Iorgu Iordan - Al. Rosetti” Institute of Linguistics, Romanian Academy, oeniculescu@yahoo.com. ** "Iorgu Iordan - Al. Rosetti” Institute of Linguistics, Romanian Academy, dialectologie@yahoo.com. *** “Iorgu Iordan - Al. Rosetti” Institute of Linguistics, Romanian Academy, danarautu@yahoo.com. ${ }^{1}$ Research Grant GAR-UM-2019 I-1.5-3; 358c/15.10.2019, with the financial support of the Donor Recurrent Fund, at the disposal of the Romanian Academy and managed through the "PATRIMONIU" Foundation.
} 
third part of the study we discuss ongoing digital retrieval programs for AFLR. Final remarks and future prospects are presented in the fourth section.

\section{The Phonogram Archive of Romanian Language (AFLR)}

AFLR stands out as being the largest and most diversified collection of dialectal texts and ethno-linguistic recordings in Romania. There are nearly 2000 reel-to-reel tapes, comprising 30 to 90 minutes per track. A monumental work in terms of design, structure and scope, The National Phonogram Archive is presently kept at "Iorgu Iordan Alexandru Rosetti" Institute of Linguistics, in Bucharest, Romania (https://www. lingv.ro/).

\subsection{Hystorical overview}

In the early1930s, D. Şandru started recording dialectal texts in different areas of the country, with modern practices for that time, representing an important step in Romanian dialectology. Between 1933 and 1948 these texts were published in Bulletin linguistique. Unfortunately, in 1944, the Bucharest Phonetic Laboratory at the Faculty of Letters was destroyed by air bombings, and along with it the invaluable collection of phonograph recordings of Romanian dialects north of the Danube was lost (VintilăRădulescu 2009).

After the Second World War, dialectal research in Romania started to flourish. In parallel with the field enquires employed for the elaboration of regional atlases, researchers gathered around the three main university centres, Bucharest, Iaşi and Cluj-Napoca, with the intent of recording and consolidating phonogram archives. Naturally, these archives differ in terms of size and methodology employed (Marin 2003, 2012).

Following the initiative of Al. Rosetti, the Phonogram Archive of the Romanian Language was founded in 1958 within the Centre for Phonetic and Dialectal Research. AFLR was set to record and transcribe authentic samples of Romanian subdialects (Şuteu 1958). In time, it would offer both a diachronic and a synchronic account of all levels across the linguistic system.

In accordance with the village network available for the three main regional atlases (Oltenia, Muntenia, Dobrogea), a systematic collection for the AFLR texts was launched. The first recordings took place in the northern part of Transylvania, in Ţara Oaşului and Ugocea (Şuteu 1958: 212). Compared to the dialectal research carried out for the atlases (with general and specific questionnaires), the AFLR enquiries are best suited for eliciting spontaneous speech, closer to the realities and source material under investigation.

In the 1990s, after the fall of the Communist regime, dialectal research outside of the country intensified, leading to recordings in The Republic of Moldova, certain areas of Ukraine, Bucovina, south-east Hungary, Bulgaria, Croatia and Serbia (see texts from TD-Ban. Sârb., TD-Bas., TD-Bulg., TD-Nistru, TD-Ucraina, TD-Ung.). In this multifaceted linguistic environment, the AFLR material reflects the speaker's linguistic and social distancing from the mother tongue, documenting cases of individual and collective bilingualism, code switching, among others (Marin et al. 2005). The material also depicts the causes and effects of losing national status, the trauma and displacement 
arising due to post war treaties reshaping national borders. Researchers also took an interest into documenting other dialects, such as Aromanian and Meglenoromanian spoken in Dobrogea, Greece, Albania, Bulgaria and the Former Yugoslav Republic of Macedonia, some of which were started in the 1960s by Nicolae Saramandu (later published in Saramandu 1972, 2003, 2005, 2007, a.o.).

Showcasing important historic events as the early as the 1907 peasant uprising, leading to First and the Second World War, the instauration of the Communist regime, the collectivization period, amongst other things, as well as well as preserving stories within the collective memory, AFLR is considered the richest collection of dialect texts in the country (Vintilă-Rădulescu 2009), being an outstanding piece of Romania's Cultural Heritage.

Alongside the audio recordings and the village notebooks, the Archive also holds various other written documents. These include catalogues, informant files, metadata records, time stamped conversation topics organized in registers, multiple manuscripts and glossary files. Also, in 1982, Victorela Neagoe and Valeriu Rusu started compiling Arhiva de scrisori şi documente dialectale [The Archive of Letters and Dialect Documents], a 1100 document collection of letters, requests, official texts, narrations, depictions of rural life and customs, poems, manuscripts and unique epigraph pictopoems from Săpânţa (Neagoe 1982, 1994, 1999).

\subsection{Past narrations within AFLR}

The AFLR recordings were assembled in a rather short time interval (1961-2019), with data collected from a dense network of over 950 villages (within the country). From each village, researchers interviewed between five and seven speakers from four generations, thus allowing the dialects to be studied in their social dynamics. According to the methodological framework described in the article which first announced the Archive (Şuteu 1958: 213), the speakers were given figures (odd numbers for female) and were grouped as following:

(i) first generation of speakers (I, II) - children between 9 and 12 years old;

(ii) second generation of speakers (III, IV) - adolescents between 18 and 22 years old;

(iii) third generation of speakers (V, VI) - adults between 35 and 45 years old;

(iv) fourth generation of speakers (VII, VIII) - adults over 60 years old.

To sum up, from a theoretical perspective, each field enquiry would generate at least eight recordings. In reality, dialectologists had to adapt and find ways of surpassing various challenges encountered along the way. For instance, the recordings taken abroad are characterized by bilingual speakers, ages 50 to 60 , since informants from the younger generation, speakers of the mother tongue, were difficult to find or, in some cases, nonexistent (see TD-Ucraina, TD-Ung.). Nevertheless, the texts within the Archive portray a diversified rendition of customs and practices identified throughout the country and abroad, each area defined by its own mentality and set of beliefs.

The Archive includes both descriptive and narrative productions, as well as numerous dialogues between the informants. Şuteu (1958: 214) sketches out a questionnaire suited for AFLR. As a result, for eliciting comparable texts, the questions were grouped as following: 
(i) questions addressed to women: How do you weave the cloth?; How do you prepare polenta?; How do you prepare the bread?; Customs at child birth (fates, christening); Customs in group work.

(ii) questions addressed to men: How is the conscription procedure?; Customs at the wedding; What are the customs surrounding ploughing?; What do you know about dragons?

(iii) questions addressed to children: What do you do in the first day of school?; How do you go carolling with Pluguşorul [= 'Small Plough']?; How do you play with other children?

For collecting more technical texts, the questions were organised in two categories:

(i) general: What have you been up to since yesterday?; Stories (from the army, from the front, at the village gatherings); memories; current challenges (regarding the collectivization period);

(ii) according to the territorial distribution plain area: What do you do between sowing and reaping?

hill side: Planting the corn, hoeing, grape harvesting; How do you make cheese? mountain side: How do you make cheese?; Working the hay; Forrest work; Special occupations (agrarian, mining, pottery, etc.).

Naturally, the questionnaire diversified over time, leading to in-depth investigation into the inter- and intra-speaker linguistic variation along with depictions of rural life. As such, AFLR is an authentic collection of ethno-texts (Neagoe 1993), portraying traditions, customs, religious practices, superstitions and folkloric productions. Due to the fact that Romanian dialect literature is believed to be absent (Vulpe 1978), these recordings are essential in linking dialectology with sociolinguistics and ethnographic research.

According to the methodology used, we distinguish between thematic and spontaneous texts. Thematic texts arise as answers to precise questions from the interviewer, describing activities of village life (building a house, raising farm animals, preparing various foods and drinks), important life events (birth, marriage, death rituals), religious or laic ceremonies, practices of traditional beliefs. These types of texts provide a complex ethno-folkloric rendering of the area under investigation. Spontaneous texts disclose narrations, historic accounts, memories, events at the sheepfold, anecdotes, jokes, and sometimes even musical performances. At the borderline between the two categories, we find testimonials regarding the village history and toponymy, folktales, legends, fables and short stories (especially delivered by children). Due to a systematic data collection, all these past narrations are comparable in nature, leading to new lines of inquiry into the oral history of the Romanian language.

\subsection{Research topics derived from AFLR}

The AFLR recordings contain phonetic productions of paralinguistic information such as changes in intensity, pitch, rhythm, as well as gestural cues, representing an important and original material from a sociolinguistic perspective. AFLR is equally relevant to onomastics studies, portraying an extensive inventory of orthonyms ranging from (nick)names of informants, to names of places accompanied by unique explanations delivered by the informants as to the age and origin of the region. From each village 
recorded there are numerous texts accompanied by oral folk productions such as poems, songs, carols, wedding orations, rendering the material ideal for comparative ethnofolkloric studies. Due to its large terminological repertoire (agriculture, shepherding, apiculture, manufacturing, viticulture, lumbering, mining, dairy, fishing, human anatomy, among others), the Archive is indispensable in conducting comprehensive analysis of dialect terminology (Marin 1996, 2003, 2012).

Various research topics, theoretical works, and projects have derived from AFLR, such as:

(i) dialectal monographs, describing the phonetic, phonological, lexical, morphosyntactic and pragmatic features of different areas in the country (TD-Sălaj) or abroad (TD-Ung., TD-Bulg., TD-Ucraina, TD-Ban. Sârb.);

(ii) anthologies reflecting the richness and the vastness of the dialectal data stored in the Archive, parts of which have been published in works referred to as "sonorous maps", "Harta sonoră" a graiurilor şi dialectelor limbii române [The Sonorous Map of the Varieties and Dialects of The Romanian Language] (Marin \& Tiugan 2014), and "Harta sonoră" a graiurilor dacoromâne vorbite în afara graniţelor României [The Sonorous Map of the Daco-Romanian Varieties Spoken Outside of Romania] (Marin et al. 2016); correlating the dialectal phonetic transcription with the literalization and the processed digitized tape recordings (on CD/DVD); similarly, a valuable anthology based on AFLR is AF I, II, coordinated by Andrei Avram;

(iii) collections of dialectal texts written in narrow phonetic transcription, gathered from a wider region $(T D M, T D O, T D D)$ or a smaller geographical area $(T D-P o r t ̧ i l e$ de Fier, $T D-B N$, a.o.);

(iv) dialectal glossaries focusing not only on the words attested in the transcribed texts, but itemizing and describing all regional terms found in the broader recorded area (Gl. Olt, Gl. Munt., TDD, TD-BN, TD-Bas., TD-Nistru);

(v) dictionaries (DGS, 3 volumes) - elaborated on the basis of the lexical material adapted from linguistic atlases (NALR-Olt, ALRR-Munt. şi Dobr.) and glossaries derived from the AFLR recordings related to varieties spoken in the southern provinces (Oltenia, Muntenia, Dobrogea);

(vi) numerous studies and articles investigating the AFLR recordings from a phonetic and phonological perspective, from a lexical and morpho-syntactic viewpoint, most of which were published in Fonetică şi dialectologie [Phonetics and Dialectology];

(vii) starting with the texts gathered from Oltenia, irrespective of the future area under investigation, there was a systematic collection of texts for AFLR regarding the values and dialectal distribution of the verbal structure (see Marin 1984, 1987, 1989a, 1989b, Neagoe 1985, a.o.);

(viii) $\mathrm{PhD}$ dissertations (Vulpe 1980, Neagoe 1983, Marin 2007).

Still, only a third of the data have been processed so far. Various manuscripts are unpublished and the remaining (text or audio) files are in urgent need of digitization. 


\section{Digitizing projects for AFLR}

Through the preservation of oral archives, we can gain access to both individual and collective memories, aiding to a better understanding of our cultural heritage on the one hand, and, on the other hand, restoring missing or forgotten pieces of Europe's oral history.

One repository of Romania's oral cultural history is the Phonogram Archive stored at the Linguistic Institute in Bucharest. The digital retrieval of this Archive started in 2006 and, so far, only 330 tapes were digitized with various attempts of restoring the hand written documents. This being said, we need to take into account both the audio tape digitization, as well as that of the metadata content (information about gender, age, regional dialect, accompanied by photographs and phonetic transcription of various pronunciation variants belonging to the informant).

\subsection{Audio retrieval}

The first recordings for AFLR were made on wax cylinders and continued with reel-to-reel tapes, from the 1960s until the 1990s, ensuring a better audio quality (Marin 2003). These oral narratives are kept either on an audio (reel-to-reel tapes and cassettes) or text format (notebooks, registers, glossaries, dialectal transcripts, numerous manuscripts). Managing such a vast collection, from storing, inventorying, to digitally retrieving, conserving and processing, comes with numerous challenges.

The equipment needed for playing these near obsolete media files, the cables required to establish a reliable and stable connection with the computer, the software indispensable for converting mainly analogue to digital format, all are extremely expensive and difficult to acquire. Decisions regarding overall costs, staff training, (post)processing, quality management need to be taken when implementing a digitizing program. Note (2011: 142-147) delivers a detailed and compelling account of the (dis)advantages of outsourcing vs in-house digital conservation of cultural heritage documents.

In 2006 the audio digitization of AFLR was initiated as an in-house protocol. Nowadays, organizing and digitally restoring the reel-to-reel tapes represents one of the fundamental preservation programs of the Romanian Academy Institute of Linguistics of Linguistics. This endeavour is carried out through Programul IX: Banca de Informare şi Documentare Lingvistică. Consevarea şi gestionarea Arhivei fonogramice a limbii române [Program IX: Information Repository and Linguistic Documentation. The Conservation and Management of The Phonogram Archive of The Romanian Language]. The team in charge of this digitization program is comprised of three members from the Dialectology and Sociolinguistics department, with only one of them working full time.

Unfortunately, due to its age and intensive usage as a result of repetitive procedures employed while phonetically transcribing the recordings started in the early 60s, only one recorder is left in working condition (see Figure 1). The situation is critical, since no more than $16.5 \%$ of the recordings have been digitized so far. Therefore, there is a pending need to develop and fund digital preservation projects so as to prevent further degradation and possible loss of the entire collection. 


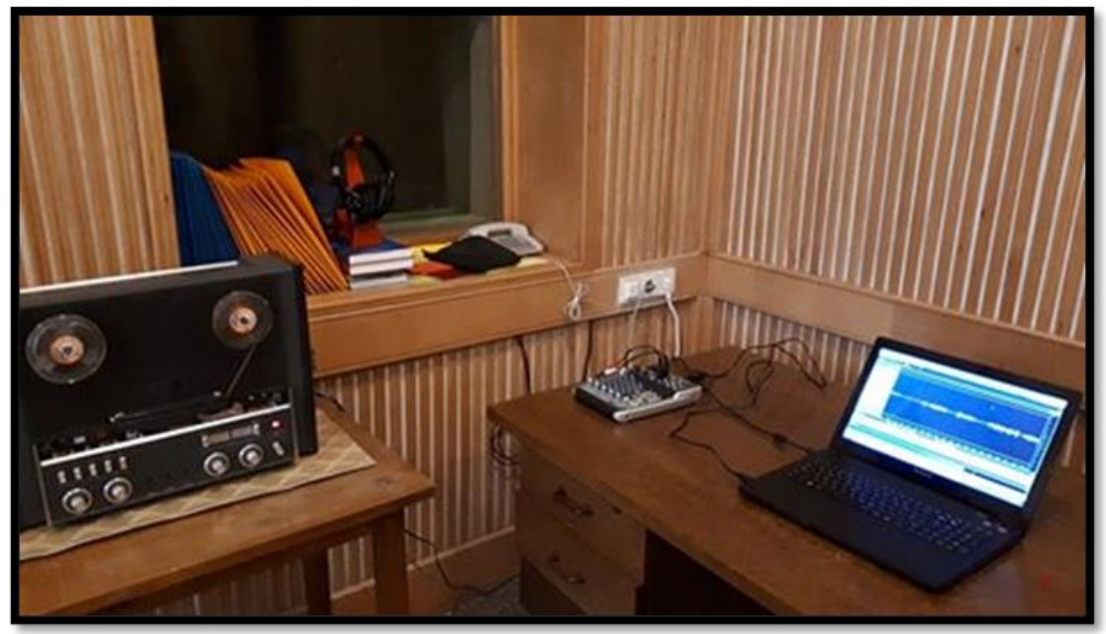

Figure 1. Digitization process of AFLR carried out in the phonetic laboratory of the "Iorgu Iordan - Al. Rosetti" Institute of Linguistics

\subsection{Text retrieval}

As a complementary route towards recovering the Archive in its entirety, the MIDVAL (= "Metode moderne de instruire şi valorificare digitală a documentelor cultural-istorice" [Modern Methods of Training and Digitally Recovering CulturalHistorical Documents]) project was initiated. Set to las two years (2019 - 2021, GARUM-2019 I-1.5-3), this digitization project is coordinated by a young research group from the Dialectology and Sociolinguistic Department of the Linguistic Institute in Bucharest. The main author is the project leader, accompanied by Daniela Răuţu and Alexandra Loizo, subsequently replaced by Mara Manta. The project is financed by the Romanian Academy Grants for Humanities through the "PATRIMONIU" Foundation. The project's research area is defined by the Digital Management of the national cultural heritage.

The general objectives of the MIDVAL project are twofold. On the one hand, the team is dedicated to digitally retrieving certain documents from the Archive (metadata files), texts considered relevant from a national cultural heritage perspective. On the other hand, the project aims to reinforce human resource performances by developing workshops and training sessions both for the personnel handling the Archive, as well as for the junior researchers working at the Institute.

In terms of document conservation, the project is built around organizing, indexing, properly storing and scanning important texts from AFLR, namely the informant's files. Since these documents faced rapid deterioration (see Figure 2), leading to an irreversible loss of valuable data, the need to develop a program such as MIDVAL was imperative.

From all recorded villages for AFLR, dialectologists collected and organized each speaker's data according to social background ("informant's file") and individual pronunciation variants ("phonogram file"). The former files specify place and date of inquiry, (nick)name of the person interviewed, age, education and current occupation, 
background information on family members (parents, spouse/husband, children) together with general observations (recording conditions, family connections, other languages spoken by the informant), and, in some cases, the subject's photograph. The latter files present topic discussions and dialect variation. After the field recordings were completed, all of these hand written texts were assembled in "village notebooks". Over 1000 such "notebooks" exist in the Archive alongside the corresponding reel-to-reel tapes.

The richness of the data stored in such "notebooks" constitutes a point of reference for various research fields (paving the way to inter- and trans-disciplinary work). Therefore, the digitization of these documents is relevant not only from a linguistic perspective, but also from a cultural heritage viewpoint. Safeguarding our oral texts from the past is a fundamental way of remembering, through social customs, folklore, time and space, our history and acknowledging our roots in the everchanging cultural environment.

In terms of staff training, MIDVAL proposes original materials (found on the project's website ${ }^{2}$ ), handouts, PPT presentations and tutorials. Thematic workshops dealing with the stages and strategies of digitizing audio and text formats from AFLR are likewise included. Another key element in the training program is getting the personnel familiarized with the technical apparatus required for the digital retrieval process. At the present moment, the website contains 12 handouts designed around the basis of data recording and data processing for AFLR, 2 video tutorials (for Adobe Audition) and a platform developed in order to facilitate acoustic recordings in the phonetic laboratory within the Linguistic Institute.

Equipping, organizing and reopening the phonetic laboratory within the host Institute are alternative steps taken in the MIDVAL project so as to optimize the workflow. The training sessions and documentation are mainly addressed (but not restricted) to the Department overseeing AFLR, so as to ensure a better navigation through the various aspects of digitization programs. We believe that cross-training existent staff is an efficient way of strengthening collaboration between individuals, leading to a proficient way of digitally restoring the Archive.

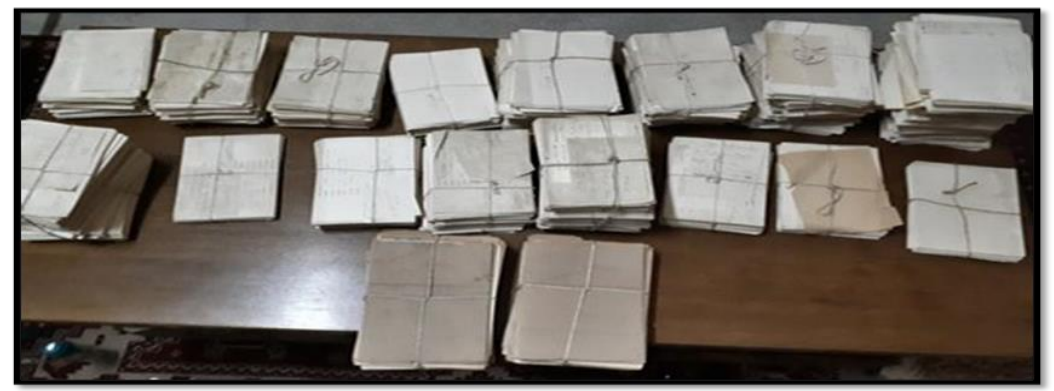

Figure 2. Preliminary retrieval of the informant's files from AFLR

The MIDVAL project is designed is such a way as to ensure support and benefits even after its completion. Among such advantages would be digital storage (plus backup files) and easy access to cultural-historical documents, the preliminary database resulted

\footnotetext{
${ }^{2}$ https://www.lingv.ro/index.php?option=com_content $\&$ view=article $\&$ id=354\&Itemid=250.
} 
after scanning the files, which can be further developed in future projects, the personnel training, collaboration and good practices embedded in each activity, the experience gained by the project's members, who can later outsource their expertise for different digitization initiatives.

\section{Conclusions}

This paper illustrated the key components of the Romanian Phonogram Archive, its contribution to past and current dialectal research as well as the ongoing digital programs orientated towards retrieving the audio and text files within the Archive.

We conclude our article by formulating the following recommendations:

(i) the need for a national program in order to create a heritage value-based management and a sustainable framework for future projects;

(ii) encouraging intercultural dialogue and raising awareness of the importance of past narrations belonging to less represented European languages;

(iii) developing resources so as to preserve this intangible cultural heritage describing not only the history of an overlooked Romance language, but also gaining a better understanding of Europe's oral history.

In order to achieve these goals, we must consider the following future prospects:

(i) taking into account EU recommendations for digital archives;

(ii) learning from existing digital archival initiatives and platforms;

(iii) initiating new dialogues not only with the members of the Academia, but also with other archival consultants, programmers, web designers, etc.;

(iv) developing new strategies and digital tools for ensuring an efficient digital retrieval of all documents within the Archive;

(v) limiting hand written texts from entering the Archive and paving the way for borndigital files;

(vi) developing an online platform for the Archive;

(vii) investing in personnel training and human resources;

(viii) providing guidance for the personnel and establishing a roadmap of best practices for digitally retrieving AFLR;

(ix) creating new opportunities for students to assist with the digital retrieval of the Archive;

(x) creating a database for AFLR;

(xi) widening the access of interested parties through various digitization projects and platforms;

(xii) considering and conducting crowdfunding campaigns for equipping and aiding the digital restoration of AFLR;

(xiii) making the Archive visible and more accessible to a broader audience;

(xiv) having a better and more consistent media visibility and impact;

(xv) allowing the public to better understand the role of the Archive in a broader cultural heritage perspective. 


\author{
Abbreviations \\ AF I, II \\ AFLR \\ ALRR-Munt. şi Dobr.
}

$D G S$

Gl. Munt.

Gl. Olt.

NALR-Olt

TD-Ban. Sârb.

TD-Bas.

$T D-B N$

TD-Bulg.

$T D D$

TDM I-III
Avram, A. (coord.), Dascălu-Jinga, L., Teodorescu, M. \& Ulivi, A. 1988 Antologia fonetică a limbii române, vol. I. Bucharest: Editura Academiei Române. Avram, A. (coord.), Mărdărescu-Teodorescu, M. \& Ulivi, A. 2006. Antologia fonetică a limbii române, vol. II. Bucharest: Editura Academiei Române.

Arhiva fonogramică a limbii române, "Iorgu Iordan - Alexandru Rosetti" Institute of Linguistics, Bucharest.

Teaha, T., Conţiu, M., Ionică, I., Lăzărescu, P., Marinescu, B., Rusu, V., Saramandu, N. \& Vulpe, M. 1996-2001. Atlasul lingvistic român pe regiuni. Muntenia şi Dobrogea, vols. I-III. Bucharest: Editura Academiei Române.

Teaha, T. (coord.), Ionică, I., Marinescu, B., Saramandu, N. \& Vulpe, M. 2004. Atlasul lingvistic român pe regiuni. Muntenia şi Dobrogea, vol. IV. Bucharest: Editura Academiei Române.

Teaha, T. (coord.), Marinescu, B. \& Saramandu, N. 2007. Atlasul lingvistic român pe regiuni. Muntenia şi Dobrogea, vol. V. Bucharest: Editura Academiei Române.

Marin, M. (coord), Ionică, I., Marin, M. Marinescu, A., Mărgărit, I. \& Teaha, T. 2009. Dicţionarul graiurilor dacoromâne sudice, vol. I. Bucharest: Editura Academiei Române

Marin, M. (coord), Ionică, I., Marin, M. Marinescu, A., Mărgărit, I. \& Teaha, T. 2010. Dicţionarul graiurilor dacoromâne sudice, vol. II. Bucharest: Editura Academiei Române.

Marin, M. (coord), Ionică, I., Marin, M. Marinescu, A., Mărgărit, I. \& Teaha, T. 2011. Dicţionarul graiurilor dacoromâne sudice, vol. III. Bucharest: Editura Academiei Române.

Marin, M. \& Mărgărit, I. 1999. Glosar dialectal. Muntenia. Bucharest: Editura Academiei Române.

Cazacu, B. (coord.), Ghiculete, G., Lăzărescu, P., Saramandu, N. \& Vulpe, M. 1967. Glosar dialectal. Oltenia. Bucharest: Editura Academiei Republicii Socialiste România.

Cazacu, B. (coord.), Teaha, T., Ionică, I. \& Rusu, V., 1967-1984. Noul Atlas lingvistic pe regiuni. Oltenia, vols. I-V: Bucharest: Editura Academiei Republicii Socialiste România.

Maria, M. (coord.), Fătu, V. M., Manta, M. I., Radu, C. I., Răuţu, D. \& Zamfir, D. M. in press. Graiuri româneşti din Banatul Sârbesc. Studiu lingvistic. Texte dialectale. Glosar. Bucharest: Editura Academiei Române.

Marin, M., Mărgărit, I., Neagoe, V. \& Pavel, V. 2000. Graiuri româneşti din Basarabia, Transnistria, nordul Bucovinei şi nordul Maramureşului. Texte dialectale şi glosar. Bucharest.

Marin, M. \& Tiugan, M. 1987. Texte dialectale şi glosar. Bistriţa-Năsăud. Bucharest.

Neagoe, V. \& Mărgărit, I. 2006. Graiuri dacoromâne din nordul Bulgariei. Studiu lingvistic. Texte dialectale. Glosar. Bucharest: Editura Academiei Române.

Lăzărescu, P., Neagoe, V., Pană, R. \& Saramandu, N. 1987. Texte dialectale şi glosar. Dobrogea. Bucharest.

Cazacu, B. (coord.), Ghiculete, G., Lăzărescu, P., Marin, M., Marinescu, B., Pană, R. \& Vulpe, M. 1973. Texte dialectale. Muntenia, vol. I. Bucharest: Editura Academiei Republicii Socialiste România.

Lăzărescu, P., Marin, M., Marinescu, B., Neagoe, V., Pană, R. \& Vulpe, M. 1975. Texte dialectale. Muntenia, vol. II. Bucharest: Editura Academiei Republicii Socialiste România. 
Rediscovering past narrations: The oral history of the Romanian language preserved in the N. Ph. A. 59

Bratu, C., Ghiculete, G., Marin, M., Marinescu, B., Neagoe, V., Pană, R., Tiugan, M. \& Vulpe, M. 1987. Texte dialectale. Muntenia, vol. III. Bucharest: Editura Academiei Republicii Socialiste România.

TD-Nistru

Marin, M., Mărgărit, I., Neagoe, V. \& Pavel, V. 2011. Graiuri româneşti de la est de Nistru. Texte dialectale şi glosar. Bucharest: Editura Academiei Române.

$T D O$

Cazacu, B. (coord.), Cohuț, C., Ghiculete, G., Mărdărescu, M., Şuteu, V. \& Vulpe, M. 1967. Texte dialectale. Oltenia. Bucharest: Editura Academiei Republicii Socialiste România.

TD-Porţile de Fier

$T D-S a ̆ l a j$

Cohuţ, C. \& Vulpe, M. 1973. Graiul din zona „Porţile de Fier”, I. Texte. Sintaxă. Bucharest: Editura Academiei Republicii Socialiste România. Graiurile din Sălaj. Studiu lingvistic. Texte dialectale. Glosar. 2017. Bucharest: Editura Academiei Române.

TD-Ucraina

Marin, M., Neagoe, V., Mărgărit, I. \& Pavel, V. 2016. Graiuri româneşti din sud-estul Ucrainei. Studiu lingvistic. Texte dialectale. Glosar. Bucharest: Editura Academiei Române.

TD-Ung.

Marin, M. \& Mărgărit, I. 2005. Graiuri româneşti din Ungaria. Studiu lingvistic. Texte dialectale. Glosar. Bucharest: Editura Academiei Române.

\section{References}

Marin, M. 1984. Valori ale perfectului compus în graiurile dacoromâne, Studii de dialectologie: 155-170.

Marin, M. 1987. Prezentul indicativ în graiurile dacoromâne. Limbă şi literatură 3: 149-163.

Marin, M. 1989a. Valori modale ale imperfectului în graiurile dacoromâne. Dialectologica: 91-98.

Marin, M. 1989b. Le passé simple dans les parlers dacoroumains actuels. Revue roumaine de linguistique 34: 305-314.

Marin, M. 1996. Arhiva fonogramică a limbii române (După 40 de ani). Revista de lingvistică şi ştiinţă literară 1: 41-46.

Marin, M. 2003. Metode şi principii în abordarea graiurilor româneşti vorbite în medii alogene. In M. Berényi (ed.), Simpozion. Comunicările celui de al XI-lea Simpozion al cercetătorilor români din Ungaria (Giula, 23-24 noiembrie 2002), 163-18. Giula: Research Institute of the Romanians in Hungary.

Marin, M. 2007. Timpuri ale indicativului în graiurile dacoromâne. Bucharest: Editura Academiei Române.

Marin, M. 2012. Arhiva fonogramică a limbii române, sursă de material pentru cercetări interdisciplinare. In M. Constantinescu, G. Stoica, \& O. Uţă Bărbulescu (eds.), Modernitate și interdisciplinaritate în cercetarea lingvistică. Omagiu doamnei profesoare Liliana Ionescu-Ruxăndoiu, 342-350. Bucharest: Editura Universităţii din Bucureşti.

Marin, M. \& Tiugan, M. 2014. Harta sonoră a graiurilor şi dialectelor limbii române [with a CD] Bucharest: Editura Academiei Române.

Marin, M., Mărgărit, I. \& Neagoe, V. 2005. Graiuri româneşti din afara graniţelor țării. Conferinţele Academiei Române, Bucharest: Editura Academiei Române.

Marin, M., Radu, C. I., Răuţu, D. \& Tiugan, M. 2016. Harta sonoră a graiurilor dacoromâne vorbite în afara graniţelor României. Bucharest: Editura Academiei Române.

Neagoe, V. 1982. Arhiva de scrisori şi documente dialectale. Anuarul ICED B 2: 474-475.

Neagoe, V. 1983. Graiul ungurenilor din nordul Olteniei. Ms., Universitatea din Bucureşti.

Neagoe, V. 1985. În legătură cu unele forme arhaice de perfect simplu şi de mai mult ca perfect şi cu unele valori ale perfectului simplu în graiurile populare actuale. Anuar de lingvistică şi istorie literară 30: 171-177.

Neagoe, V. 1993. Etnotext şi text dialectal. Fonetică şi dialectologie 12: 123-132.

Neagoe, V. 1994. Despre arhiva dialectală scrisă a limbii române. Studii şi cercetări lingvistice 45: 51-56.

Neagoe, V. 1999. Din arhiva de scrisori şi documente dialectale. Texte scrise de Pătru Vlad din com. Cerbăl, jud. Hunedoara (Ţinutul Pădurenilor). Fonetică şi dialectologie 18:179-210.

Note, M. 2011. Managing Image Collections. A Practical Guide. Oxford: Chandos Publishing. 
Saramandu, N. 1972. Cercetări asupra aromânei vorbite în Dobrogea. Fonetică. Observaţii asupra sistemului fonologic. Bucharest: Editura Academiei Republicii Socialiste România.

Saramandu, N. 2003. Studii aromâne şi meglenoromâne. Constanţa: Editura Ex Ponto.

Saramandu, N. 2005. Structura aromânei actuale. Graiuri din Dobrogea. Texte dialectale. Bucharest: Editura Academiei Române.

Saramandu, N. 2007. Aromâna vorbită în Dobrogea. Texte dialectale. Glosar. Bucharest: Editura Academiei Române.

Şuteu, V. (1958). Arhiva fonogramică a limbii române. Fonetică şi dialectologie 1: 211-219.

Vintilă-Rădulescu, I. (coord.). 2009. Academia Română, Institutul de Lingvistică „Iorgu Iordan - Al. Rosetti” din Bucureşti, 60 de ani de existenţă (1949-2009). Bucharest: Editura Univers Enciclopedic.

Vulpe, M. 1978. Romanian dialectology and sociolinguistics. Cahiers de linguistique théorique et appliquée, 23 (1-4): 293-328.

Vulpe, M. 1980. Subordonarea în dacoromâna vorbită. Bucharest: Editura Ştiinţifică şi Enciclopedică. 